\title{
Inoscavin E, a Free Radical Scavenger from the Fruiting Bodies of Inonotus xeranticus
}

\author{
In-Kyoung Lee, Young-Sook Kim, Soon-Ja Seok, Bong-Sik Yun
}

Received: September 27, 2007 / Accepted: December 2, 2007

(C) Japan Antibiotics Research Association

\begin{abstract}
A new free radical scavenger named inoscavin $\mathrm{E}$ was isolated from the fruiting bodies of Inonotus xeranticus. Its structure was determined as 2-(3,4dihydroxyphenyl)-6-[(1E)-2-(3,4-dihydroxyphenyl)ethenyl]$4 H$-furo[3,2-c]pyran-4-one on the basis of spectroscopic analysis. Inoscavin E exhibited significant scavenging activity against the superoxide radical anion and ABTS radical cation.
\end{abstract}

Keywords inoscavin E, Inonotus xeranticus, free radical scavenger

Inonotus xeranticus (Berk.) Imaz. Et Aoshi. (Hymenochaetaceae) is a saprophytic fungus preferably living on deciduous trees and widely distributes in East Asia [1]. In previous investigation on antioxidant constituents from this mushroom, we isolated several free radical scavengers, inoscavins $\mathrm{A} \sim \mathrm{D}$ [2] and interfungins $\mathrm{A} \sim \mathrm{C}$ [3]. Our continuing search for new antioxidant principles from this material, a new free radical scavenger, designated as inoscavin $\mathrm{E}$, has been isolated. In this paper, the isolation, structure determination, and free radical scavenging activity of inoscavin $\mathrm{E}$ are described.

The fresh fruiting bodies of Inonotus xeranticus were crushed and extracted with methanol at room temperature. The methanolic extract was concentrated under reduced pressure and the aqueous resultant was partitioned with hexane. The hexane layer was discarded, and EtOAc was

B.-S. Yun (Corresponding author), I.-K. Lee, Y.-S. Kim: Functional Metabolites Research Center, KRIBB, 111 Gwahangno, Yuseong-gu, Daejeon 305-806, Korea,

E-mail: ybs@kribb.re.kr added to the water phase and shaken. The EtOAc layer was concentrated and subjected to a column of Sephadex LH-20 eluting with a mixture of $\mathrm{CHCl}_{3}: \mathrm{MeOH}(1: 1, \mathrm{v} / \mathrm{v})$. The antioxidant fraction was rechromatographed on a column of Sephadex LH-20 eluting with $\mathrm{MeOH}$ only, followed by reversed-phase column chromatography eluting with $70 \%$ aqueous $\mathrm{MeOH}$. Finally, $4.0 \mathrm{mg}$ of inoscavin $\mathrm{E}$ was purified by preparative reversed-phase TLC developed with $80 \%$ aqueous $\mathrm{MeOH}$.

The molecular weight of inoscavin $\mathrm{E}$ was determined to

$$
\begin{aligned}
& \text { Fruiting bodies of Inonotus xeranticus }(5 \mathrm{~kg}) \\
& \text { extracted with } \mathrm{MeOH} \\
& \text { concentrated in vacuo } \\
& \text { partitioned between hexane and water } \\
& \text { Water layer } \\
& \text { | extracted with EtOAc } \\
& \text { EtOAc layer } \\
& \text { | concentrated in vacuo } \\
& \text { Sephadex LH-20 column chromatography } \\
& \text { eluted by } \mathrm{CHCl}_{3}: \mathrm{MeOH}(1: 1, \mathrm{v} / \mathrm{v}) \\
& \text { Sephadex LH-20 column chromatography } \\
& \text { | eluted by } \mathrm{MeOH}
\end{aligned}
$$

Fig. 1 Isolation procedures of inoscavin E.
S.-J. Seok: National Institute of Agricultural Science and Technology, RDA, Suwon 441-707, Korea 
Table $1{ }^{1} \mathrm{H}$ - and ${ }^{13} \mathrm{C}$-NMR data of inoscavin $\mathrm{E}$ in $\mathrm{CD}_{3} \mathrm{OD}$

\begin{tabular}{|c|c|c|}
\hline No. & $\delta_{\mathrm{C}}$ & $\delta_{\mathrm{H}}$ \\
\hline 2 & 158.3 & \\
\hline 3 & 100.3 & $6.96(1 \mathrm{H}, \mathrm{s})^{a}$ \\
\hline 3a & 112.3 & \\
\hline 4 & 161.3 & \\
\hline 6 & 158.5 & \\
\hline 7 & 96.5 & $6.83(1 \mathrm{H}, \mathrm{s})$ \\
\hline $7 a$ & 162.7 & \\
\hline $1^{\prime}$ & 122.3 & \\
\hline $2^{\prime}$ & 112.6 & $7.20(1 \mathrm{H}, \mathrm{d}, J=2.0 \mathrm{~Hz})$ \\
\hline $3^{\prime}$ & 146.9 & \\
\hline $4^{\prime}$ & 148.0 & \\
\hline $5^{\prime}$ & 116.8 & $6.83(1 \mathrm{H}, \mathrm{d}, J=8.4 \mathrm{~Hz})$ \\
\hline $6^{\prime}$ & 117.9 & $7.16(1 \mathrm{H}, \mathrm{dd}, J=8.4,2.0 \mathrm{~Hz})$ \\
\hline $1^{\prime \prime}$ & 117.4 & $6.70(1 \mathrm{H}, \mathrm{d}, J=16.0 \mathrm{~Hz})$ \\
\hline $2^{\prime \prime}$ & 135.5 & $7.30(1 \mathrm{H}, \mathrm{d}, J=16.0 \mathrm{~Hz})$ \\
\hline $3^{\prime \prime}$ & 129.3 & \\
\hline $4^{\prime \prime}$ & 114.6 & $7.04(1 \mathrm{H}, \mathrm{d}, J=2.0 \mathrm{~Hz})$ \\
\hline $5^{\prime \prime}$ & 146.8 & \\
\hline $6^{\prime \prime}$ & 148.3 & \\
\hline $7^{\prime \prime}$ & 116.6 & $6.77(1 \mathrm{H}, \mathrm{d}, J=8.0 \mathrm{~Hz})$ \\
\hline $8^{\prime \prime}$ & 121.7 & $6.95(1 \mathrm{H}, \mathrm{dd}, J=8.0,2.0 \mathrm{~Hz})$ \\
\hline
\end{tabular}

${ }^{a}$ Integral, multiplicity and coupling constants in parentheses.

be 378 by the ESI-mass measurements providing a quasimolecular ion peaks at $\mathrm{m} / z 401[\mathrm{M}+\mathrm{Na}]^{+}$in positive mode and at $m / z 377[\mathrm{M}-\mathrm{H}]^{-}$in negative mode. Its molecular formula was established as $\mathrm{C}_{21} \mathrm{H}_{14} \mathrm{O}_{7}$ by the high-resolution ESI-mass measurement $\left(\mathrm{m} / \mathrm{z} 379.0[\mathrm{M}+\mathrm{H}]^{+}, \Delta+3.7 \mathrm{mmu}\right)$ in combination with ${ }^{1} \mathrm{H}$ - and ${ }^{13} \mathrm{C}-\mathrm{NMR}$ data. This molecular formula requires 15 degrees of unsaturation. The ${ }^{1} \mathrm{H}-\mathrm{NMR}$ spectrum of inoscavin E showed two AMX spin systems assignable to two 1,2,4-trisubstituted benzene moieties at $\delta 7.20(1 \mathrm{H}, \mathrm{d}, J=2.0 \mathrm{~Hz}), 7.16(1 \mathrm{H}, \mathrm{dd}, J=8.4$, $2.0 \mathrm{~Hz})$ and $6.83(1 \mathrm{H}, \mathrm{d}, J=8.4 \mathrm{~Hz})$, and $\delta 7.04(1 \mathrm{H}, \mathrm{d}$, $J=2.0 \mathrm{~Hz}), 6.95(1 \mathrm{H}, \mathrm{dd}, J=8.0,2.0 \mathrm{~Hz})$ and $6.77(1 \mathrm{H}, \mathrm{d}$, $J=8.0 \mathrm{~Hz}$ ), two $s p^{2}$ methine singlets at $\delta 6.96$ and 6.83 and two olefinic methine doublets attributable to a trans-1,2disubstituted double bond at $\delta 7.30(1 \mathrm{H}, \mathrm{d}, J=16.0 \mathrm{~Hz})$ and $6.70(1 \mathrm{H}, \mathrm{d}, J=16.0 \mathrm{~Hz})$. The ${ }^{13} \mathrm{C}-\mathrm{NMR}$ spectrum exhibited 21 carbons, which were established as ten $s p^{2}$ methines and eleven $s p^{2}$ quaternary carbons by the aid of the HMQC spectrum. Eight signals of quaternary carbons were proposed to be ester carbonyl or oxygenated $s p^{2}$ carbons from their chemical shift values between $\delta 146$ to 163 (Table 1). The structure of inoscavin $\mathrm{E}$ was determined by the HMBC spectrum, as shown in Fig. 2. The proton NMR spectrum showing a methine singlet at $\delta 6.83$, AMX spin
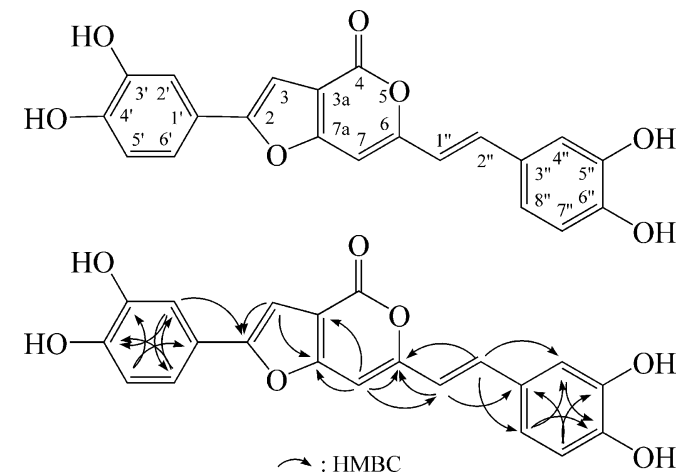

Fig. 2 Structure and $H M B C$ correlations of inoscavin $E$.

system in aromatic region and two olefinic methine doublets, and the UV absorption bands at $\lambda_{\max }(\mathrm{MeOH})$ $(\log \varepsilon) 411$ (4.23), 325 (3.96) and 316 (3.92) nm suggested the presence of conjugated hispidin moiety, which was ubiquitous structure in mushroom polyphenols $[4,5]$. This was also supported by the long-range correlations of $\mathrm{H}-7$ to C-3a, C-7a, C-6, and C-1", H-1" to C-6 and C-3", H-2" to C-6, C-4" and C-8", H-4" to C-6" and C-8", H-7" to C-3" and $\mathrm{C}-5^{\prime \prime}$, and $\mathrm{H}-8^{\prime \prime}$ to $\mathrm{C}-4^{\prime \prime}$ and $\mathrm{C}-6^{\prime \prime}$, and these chemical shift values were consistent with the corresponding protons and carbons of hispidin moiety [3,5]. Additional longrange correlations from $\mathrm{H}-3$ to $\mathrm{C}-2$ and $\mathrm{C}-7$ a revealed that a furan moiety was fused with hispidin. A remaining 1,2,4trisubstituted benzene group was connected to $\mathrm{C}-2$ by the HMBC correlation from $\mathrm{H}-2^{\prime}$ to $\mathrm{C}-2$. By the process of elimination, a remaining ester carbonyl carbon at $\delta 161.3$ should be positioned to C-4. Therefore, the structure of inoscavin $\mathrm{E}$ was unambiguously determined as 3-deacetyl inoscavin $\mathrm{C}$, a new antioxidant polyphenol with hispidin moiety.

Antioxidant activity of inoscavin E was evaluated by measuring free radical scavenging activity using three different radical species, the ABTS $\left(2,2^{\prime}\right.$-azino-bis(3ethylbenzothiazoline-6-sulfonate)) radical cation, superoxide radical anion and DPPH (1,1-diphenyl-2-picrylhydrazyl) radical. ABTS radical scavenging activity was carried out by using ABTS radical cation decolorization assay with minor modifications [6]. Inoscavin $\mathrm{E}$ exhibited potent ABTS radical cation scavenging activity with an $\mathrm{IC}_{50}$ value of $22 \mu \mathrm{M}$, which was higher activity than trolox $\left(\mathrm{IC}_{50}\right.$, $30 \mu \mathrm{M}$ ), a well-known antioxidant used as control, and less activity than caffeic acid $\left(\mathrm{IC}_{50}, 10 \mu \mathrm{M}\right)$. Superoxide radical anion scavenging activity was evaluated by the xanthine/xanthine oxidase method with minor modifications [7]. Although it was three-times less active than caffeic acid, a well-known superoxide radical 
scavenger, inoscavin E displayed significant superoxide radical anion scavenging activity with an $\mathrm{IC}_{50}$ value of $49 \mu \mathrm{M}$. However, inoscavin E showed no DPPH radical scavenging activity up to $100 \mu \mathrm{M}$.

Acknowledgements This work was supported by the Korea Research Foundation Grant (KRF-2006-532-F00002) from the Korean Government (MOEHRD) and by a grant (20050401-034645-196) from the BioGreen 21 Program of the Rural Development Administration (RDA), Korea.

\section{References}

1. Imazeki R, Hongo T. In Colored Illustrations of Mushrooms of Japan. Hoikusha, Osaka, 1989, Vol. 2, p. 495

2. Lee IK, Jung JY, Seok SJ, Kim WG, Yun BS. Free radical scavengers from the medicinal mushroom Inonotus xeranticus and their proposed biogenesis. Bioorg Med Chem Lett 16: 5621-5624 (2006)

3. Lee IK, Yun BS. Highly oxygenated and unsaturated metabolites providing a diversity of hispidin class antioxidants in the medicinal mushrooms Inonotus and Phellinus. Bioorg Med Chem 15: 3309-3314 (2007)

4. Fiasson JL. Distribution of styrylpyrones in the basidiocarps of various Hymenochaetaceae. Biochem Syst Ecol 10: 289-296 (1982)

5. Fiasson JL, Gluchoff-Fiasson K, Steglich W. Pigments and fluorescent compounds from Hypholoma fasciculare (Agaricales). Chem Ber 110: 1047-1057 (1977)

6. Re R, Pellegrini N, Proteggente A, Pannala A, Yang M, Rice-Evans C. Antioxidant activity applying an improved ABTS radical cation decolorization assay. Free Radic Biol Med 26: 1231-1237 (1999)

7. Kirby AJ, Schmidt RJ. The antioxidant activity of Chinese herbs for eczema and of placebo herbs-1. J Ethnopharmacol 56: 103-108 (1997) 